\title{
Underpricing of Initial Public Offerings: A Literature Review
}

\author{
Supriya Katti ${ }^{*}$ B.V. Phani \\ Department of Industrial and Management Engineering, Indian Institute of Technology, India
}

Copyright $(2016$ by authors, all rights reserved. Authors agree that this article remains permanently open access under the terms of the Creative Commons Attribution License 4.0 International License

\begin{abstract}
Rock's [1] theory ascertains information asymmetry as a primary reason to answer "Why New Issues are Underpriced?" Theoretical construct of this seminal work is based on information asymmetry between various classes of investors. Empirical manifestation of this theoretical explanation is based on considering different proxy measures to quantify the information asymmetry as perceived by various researchers over the past three decades. The growing IPO literature also explained underpricing with the help of agency theory, signaling, behavioural theories etc. Empirical research has identified various determinants of IPO underpricing. The influence of various factors predominantly depends upon country specific regulations, market microstructure and price discovery mechanism. Although many factors have justified the degree of underpricing, controlling for these factors does not completely eliminate the degree of under pricing. The justification of residual underpricing through these factors has limitations in terms of failure to completely explain the IPO underpricing. The paper reviews different factors presented in the extant literature that influence the price discovery mechanism of initial public offerings (IPO) in various economies. We conclude that the degree of underpricing is dynamic and various markets forces interact simultaneously in observing the variation in pricing the new equity issues. This paper points out the significance of regulatory framework in explaining the degree of IPO underpricing.
\end{abstract}

Keywords Underpricing, Information Asymmetry, Signaling

\section{Introduction}

Demand uncertainty adds to the complexity of pricing the goods and services. Since the supplier and consumer have different perceived values of a particular goods and services to be sold under a time constraint, this would also force the supplier to underprice the goods or services to be able to complete the sale. This is further accentuated in case of information asymmetry between the supplier and the consumer or within various classes of consumers regarding the goods and services offered.

The above has been found to be true particularly in case of new equity issues by a firm through an initial public offering (IPO). In this case the seller has to ensure that securities offered at a particular price are attractive to all the classes of investors to induce the necessary demand. Rock [1] defines various classes of investors based on the degree of information asymmetry and other market constraints they face. Given the time constraint in terms of the offer being made, the firm has to incur the cost of equity issuance. Therefore, unsuccessful offers result in high cost and has negative spillover effect associated with the failure of the issue. The need for capital creates a situation where it is extremely critical for the seller to sell the securities within specified time frame. This creates a bias in terms of the perceived value of the transaction between the buyer and seller.

Given the above, initial equity issuance or IPO to the general public is subject to greater risk since certain class of investors may perceive lack of sufficient information in spite of the best efforts of the issuing firm and their underwriters. The risk is further accentuated by constraints on a) the time during which the transaction needs to be completed, b) the price with limited or no price adjustment allowed during the transaction period once the offer is made, and c) the size of the offer being made relative to the investor's available wealth.

The difference between the perceived value of equity between the issuer and the investors results in IPO underpricing. This gets influenced by various endogenous and exogenous factors either in mitigating or accentuating the difference in the perception. In this paper we try to elaborate on various factors by compiling and categorizing them through existing literature.

Early evidence of IPO underpricing in the extant literature is attributed to Reilly and Hatfield [2] in their paper titled "Investor Experience with New Stock Issues". In this paper they examined a limited dataset of 53 new equity offerings 
for a period between December, 1963 to August, 1964 and January, 1965 to June, 1965. They analyzed the immediate performance by considering IPO return between offer price and price on the first Friday after the listing. The results indicated that more than $50 \%$ (31 stocks) of the issues outperformed the market in the short run fetching average return of $18.3 \%$ compared to the market. The study observed superior performance of new issues by analyzing the returns on the first Friday, fourth Friday and after one year from issuance. However, the study suffered from two limitations one is the period of study was hot market period as acknowledged by the authors wherein the demand for first time issues was significantly higher and secondly the excess return was bench marked with the returns of Dow Jones Index which is a price weighted index. They also reported that the excess returns observed are significantly lower when compared with Over the Counter Industrial average.

Reilly and Hatfield [2] tautologically provided several possible reasons for observing superior returns and concluded that the new equity issues are underpriced. Their a priori reasons are mainly focused on the prevailing mechanism wherein the issuer arrives at a price in consultation with the underwriter. They contend that the observed underpricing can occur 1) due to the unseasoned nature of the issue, underwriters are unable to judge the investors evaluation of new equity issues 2) underwriters deliberately underprice to ensure the success of the issue and any oversubscription will lead to higher first day returns 3) underwriters would like to minimize their exposure with a quick sale since they have relatively smaller capital bases for the amount of underwriting they undertake and 4) given that under Securities and Exchange Commission (SEC) supervision underwriters are permitted to undertake stabilizing action in case of higher volatility which ties up their capital and resources, they would underprice since successful issues does not require their intervention and 5) since underwriters receive part of their fees in the form of stock or have an option to purchase a large block of stock at a price near or below the issue price and they benefit directly from a successful issue. On the other hand, the issuer is willing to accept lower proceeds to leave good taste in investors' mouth so that future issues will also be successful. This is important from firm's perspective since the capital need of a firm is not completely satisfied through a single equity offer. As a result the issuer would like to accept lower proceeds in anticipation of fulfilling any future capital requirement from these new stockholders.

The above cited reasons highlights that the degree of underpricing is induced when the objectives of the underwriter, issuer and the investors are not aligned. The difference between the objectives of the underwriter, issuer and subscriber has been further explored by many researchers. Various theoretical constructs, linking the objectives of the issuer, underwriter as well as the investors have been proposed. These constructs use various existing theories collectively and individually like the Agency Theory, Efficient Market Hypotheses, Contract Theory,
Information Asymmetry, Signaling Theory etc. to rationalize the underpricing observed and also the variance of the observed underpricing. Attempts have been made to validate these constructs through various empirical studies undertaken by various researchers over the years.

The OECD review paper of Rhee [3] observed that short term underpricing and long term underperformance phenomenon is still prevalent and yet unresolved puzzle since the early studies of Reilly and Hatfield [2]. He observed that the average first day return for US IPOs was $24.19 \%$ during the 12 year period of $1990-2001$. On the contrary, Purnanandam and Swaminathan [4] show that the median IPO firm is overvalued by about $50 \%$ relative to its industry peers. His review confirms that the phenomenon is not limited to only U.S. but is observed in almost all countries where IPOs are in vogue.

In the case of underpricing academic literature proposes information asymmetry as a primary reason. The literature proposes that underpricing could be attributed to information asymmetry at two levels 1) Issuer and Underwriter (Baron [5]; Muscarella and Vetsuypens [6] 2) Informed investors and Uninformed investors (Rock [1]). The review by Rhee [3] also states that other than information asymmetry a stream of literature has proposed that many times firms like to use degree of IPO underpricing as a mechanism for signaling (Allen and Faulhaber [7]; Grinblatt and Hwang [8]; and Welch $[9,10])$. Other than the above reasons the paper also states that there are few studies which focus on specific factors like ex-ante uncertainty (Beatty and Ritter [11]), quality of advising agents (Booth and Smith [12]; Titman and Trueman [13]; Balvers [14]; Carter and Manaster [15]; Carter [16]) and premium for probable material misstatements (Tinic [17]; and Hughes and Thakor [18] ).

Rhee [3] summarizes the reasons for long term underperformance by reviewing extant literature with the help of three major explanations 1) The "Windows of Opportunity" (Ritter [19]; and Loughran and Ritter [20]) or the "Fads" hypothesis (Shiller [21]; Camerer [22]) 2) The Agency Cost Hypothesis (Jensen [23]) and 3) The Earnings Management hypothesis (Jain and Kini [24]; Cai and Loughran [25]).

Ritter and Welch [26] reviewed and examined IPO activity between 1980 and 2001. The increasing IPO activity during this period is mainly due to changing composition of the issuers. They find significant increase in technology driven firm issuing IPOs. Their review identified various reasons of IPO underpricing under the condition of asymmetric information (Baron [5]; Rock [1]; Muscarella and Vetsuypens [6]; Welch [9,10]; Allen and Faulhaber [7]; Chemmanur [27]; Jegadeesh, Weinstein, and Welch [28]; Michaely and Shaw [29]; Koh and Walter [30] ) and symmetric information (Tinic [17]; Hughes and Thakor [18]; Drake and Vetsuypens [31]; Lowry and Shu [32]; Boehmer and Fishe [33]; Krigman, Shaw, and Womack [34]; Ellis [35] and Booth and Chua [36] ). This review paper also discusses the literature that addressed the allocation bias in the IPO process. Their review concludes that underpricing is 
observed ubiquitously in IPO market and is cyclical in nature. Various studies have formed theory of information asymmetry as a basis for explaining the degree of underpricing. However, according to Ritter and Welch [26], theory of information asymmetry is been overemphasized in the academic literature. There is not a single generalized theory that can explain the reason for observing underpricing. It is very likely that particular reason of underpricing can potentially be valid for particular firm/s at particular point of time in a particular economy. Long term underperformance is supported with the critic that it largely depends upon the methodology and time period of the study.

Yong [90] presented a comprehensive review of Asian IPOs. According to this review, the Asian IPOs also experience IPO underpricing due to unique factors associated with Asian IPOs. The paper mentioned few unique factors. In Japan the listing requirements are quite stringent. Therefore, Japanese firms are larger and older at the time of going public. The decision making process of Japanese firms is often centralized with the president. In Asian market, the information content disclosed to prospective investors also differs. The access to financial information, earnings forecast, accuracy of the information, audit quality and reputation of auditing firm influences the information available to the prospective investors while making the investment decision. In addition, commonly observed factors such as ownership structure, group affiliation, reputation of underwriter, price discovery mechanism of book building versus auction, involvement of venture capitalist etc. also have influence in determining the degree of underpricing of Asian IPOs. This paper also points out certain unique characteristics of Asian IPOs that play significant role in the process of IPO. Different classes of equity shares in China (A class shares or B class shares) change the composition of investors' class. The paper also points out that many Asian countries such as India, Singapore, Thailand, Hong Kong and Bangladesh favor small investors. This results in biased allocation of IPO shares. Due to these differences in the Asian market, the results of IPO performance sometimes may not be consistent as compared to other economies.

Given the enormous amount of extant literature in the IPO domain, this paper is designed to discuss some important theories of IPO underpricing. The objective this paper is also to categorize various endogenous and exogenous factors determining the degree of IPO underpricing.

To present the review of IPO underpricing, we considered most of the papers that are searched through EBSCO, ScienceDirect, ProQuest, JSTOR and Google Scholar searched with key word "IPO Underpricing", "IPO", "New equity Issue". The studies are also considered which are cited frequently by various authors. Based on this methodology, we present the following review of IPO underpricing.

\section{Information Asymmetry}

The positive return on the listing day or degree of IPO underpricing has been observed ubiquitously. Majority of the studies attribute information asymmetry as one of the primary reason for observing degree of underpricing. Information asymmetry is observed at two different interfaces. First one is been identified between the issuer and the underwriter and second one is between the underwriter and the investors or various classes of investors (market). The degree of information asymmetry is a function of issue mechanism opted by the issuer or underwriter. The degree of information asymmetry is accentuated with the fixed price or auction price mechanism wherein the underwriter has superior information and plays significant role as a price setter and distributor of shares. These issue mechanisms have single price point resulting in higher probability of mispricing the issue. Therefore these two price mechanisms lead to adverse selection. In case of book building mechanism the price range helps in accommodating some degree of information asymmetry where investors can submit their bids in the subscribed price range. The degree of underpricing occurred due to information asymmetry depends on the difficulty faced by the issuer in estimating the magnitude of information asymmetry between various classes of subscribers i.e. informed and uninformed investors. Therefore, to eliminate the probability of issue failure the issuer/underwriter is likely to induce the degree of underpricing by lowering the issue price intentionally. Following section reviews various studies based on information asymmetry as one of the reason for observing underpricing.

Early researchers have identified and modeled information asymmetry as one of the important determinant of IPO underpricing (Baron [5]; Rock [1]; Welch [10]). The literature identifies information asymmetry at two different levels that is the information asymmetry between the issuer and the underwriter and information asymmetry among various classes of investors. The magnitude of information asymmetry also differs at different levels which lead to significant difference in the price perception.

Baron and Holmström [37]; Baron [5] assume information asymmetry between the issuer and the underwriter. They hypothesize that underwriters are better informed than the issuer about the market demand. The underwriters take advantage of this superior information by inducing the degree of underpricing to minimize their distribution efforts. On the other hand issuer being at informational disadvantage is forced to accept the lower price. However, this price would be still higher than the price perceived by the issuer. The dynamic relationship between the issuer and the underwriter is explained with the help of principle - agent problem where underpricing is used by the underwriter to minimize their distribution efforts. This model supports the divergence of objectives between the issuer and underwriter which is primarily temporal in nature. The underwriters' achieve their objective at the cost of fetching lower proceeds for the issuer.

Muscarella and Vetsuypens [6] empirically tested Baron's model [5] of agency theory related argument as an evidence for observing underpricing. They studied 38 IPOs by U.S. 
investment bankers during the period of 1970 to 1987 and analyzed a situation where the issuer and the underwriter are one and the same. This situation allows complete elimination of agency related problem and information asymmetry between the issuer and the underwriter. In spite of such set up, Muscarella and Vetsuypens [6] found evidence of significant underpricing of these IPOs which is comparable to the underpricing of other IPOs. Therefore, this study does not support the agency theory based explanation of underpricing put forth by Baron [5] although the study draws its interpretation based on very limited sample size.

Beatty and Ritter [11], Benveniste and Spindt [38] established a significant relationship between intermediation of underwriter and degree of information asymmetry. Beatty and Ritter [11] studied 1028 U.S. IPOs between the period of 1977 and 1982. In this study they pointed out that the degree of underpricing is induced through underwriter. They also find that since the issuer is aware about the existence of degree of information asymmetry he is likely to make an attempt to reduce firm specific ex ante uncertainties.

Rock [1] modeled the possibility of existence of information asymmetry between the various classes of investors'. In this model he assumes role of the issuer and underwriter as one and the same and there is no agency conflict between them. Information disclosure through the draft documents is available to all the investors. Due to availability of limited information and subjectivity associated with the future growth estimates makes the investment in IPO a risky proposition. Given this, investors would like to access as much information as possible regarding the company and the issue. Obtaining meaningful information is difficult and expensive for the investors. All the prospective investors may not be willing to incur the cost to obtain the information. Even when information is available the noise associated with such information makes it difficult to extract any value from the same. The complete set of investors might suffer from a varying degree of information asymmetry and the literature has broadly classified the same into informed investors and uninformed investors. Informed investors, who are primarily institutional investors, benefit by the additional information that outweighs the cost incurred to acquire the same due to their economies of scale. In this case the uninformed investors face 'winner's curse' because they will get the allocation of only overpriced shares which are not subscribed by the informed investors.

The literature also addresses the existence of degree of information asymmetry between the investors' classes who participate in the issue for the investment purpose. Miller [39] states that participation by different classes of investors creates heterogeneity of investment objectives among various classes of investors. Heterogeneity of investment objectives results in divergence of opinion about the firm value. These differences in the valuation lead to a noise and influence pricing of the security. Informed investors incur cost to obtain the information therefore their expectation about the return on investment includes compensation for the information cost. The issuer is interested in attracting both the classes of investors to make the issue successful because uninformed investors are perceived as strategic investors and investment by them is normally targeted for a longer period. It is observed that full subscription to an issue in most cases is related to the level of participation by uninformed investors.

In such situation even though the issuer is aware of the disparity between the information content available between different categories of investors, it becomes very difficult to judge the variance and magnitude of the degree of information asymmetry that exists. The complexity involved in quantifying this judgment gets exacerbated in a situation when the issuer is at informational disadvantage compared to the collective information available with the market as a whole (Rock [1]). To address this, the issuer will opt to make full disclosure of available information and strive for wide and rapid dissemination of the same. Even then as mentioned earlier the subjectivities involved in the valuation of the firm might be perceived differently by different categories of investors. Therefore, the issuer faces a problem of setting the offer price in such a way that it signals attractive investment opportunity for both the classes of investors and also ensure the success of the issue. Rock [1] identified that if the offer price is perceived to have a larger degree of underpricing (or set very low), then informed investors hesitate to participate in the process of IPO, as the offer price is then taken as a signal that their informed estimate has not fully captured the inherent risk. This will lead informed investors not to participate in the issue and uninformed investors garnering most of the allocation of "bad issue". If the issue is underpriced to a smaller degree (offer a discount), then informed investors will perceive it as an opportunity for a quick return, compensation for the cost of information acquisition and therefore crowd in. In that case the probability of receiving allocation to an uninformed investor gets reduced. This leads to the lemon problem and impacts the confidence of the retail investors since they become the victims of winners' curse. Therefore, setting an optimal offer price, rewarding the superior information or compensate for the cost of information that ensures the success of the issue and also control the negative signals simultaneously in the process of IPO are some of the major challenges for the issuer.

The issuer can control endogenous nature of various uncertainties by providing more information to the investors with the objective of reducing degree of information asymmetry. Ironically, investors do not necessarily make use of all the information obtained by them for the valuation purpose. Information cascading theory proposed by Welch [10] postulates that investors create information cascade by following sequential sales and rely on the decision of other investors who exhibit purchasing decision earlier. This creates bandwagon effect and investors completely ignore the information obtained by them. This is further quoted as "herd behavior" of investor occurred due to dynamic information. This is potentially avoided by maintaining the 
confidentiality of investors' identity those who participate in the early phase of issuance. The process of book building is likely to discourage this kind of investor behavior.

The above mentioned studies indicate the challenge faced by the issuer to have judgment of variance in the magnitude of degree of information asymmetry, resulting in IPO underpricing. The relationship between degree of underpricing and information asymmetry is observed as a cause and effect where issuer is bound to accept the price decided by the underwriter. The regulatory environment in the process of IPO significantly controls the degree of information asymmetry. If the bidding by various investors is transparent in the IPO process where the information is displayed actively to the public, then participation of retails investors significantly depends upon the participation of institutional investors and also get benefited if they base their investment decision by observing the bidding by institutional investors (Khurshed [40]; Neupane and Poshakwale [41]). In addition existence of active grey market, as observed in India, drives market sentiments that influence the process of price discovery and decision of retail investors (Brooks [42]; Neupane [43]). The process is very similar to information cascading theory proposed by Welch [10]. This reveals that if the process of investors' participation is transparent, it reduces the degree of information asymmetry among the various classes of investors.

Country specific regulator can opt to have various mechanisms to reduce the degree of information asymmetry. Deb and Marisetty [44] identified the success of IPO grading introduced by Indian regulator which helped the retail investors to signal the quality of IPO. IPO grading also helped in reducing the degree of underpricing for Indian IPOs. The discretionary powers allocated to the underwriter significantly control the pricing and aftermarket activities related to IPO (Bubna and Prabhala [45]; Aggarwal [46]).

The degree of information asymmetry differs for emerging and developed markets. It is further accentuated by other endogenous and exogenous factors which are considered as a source for the overall degree of underpricing. Signaling theory propose that issuer takes the opportunity of underpricing to signal the quality of the firm.

\section{Signaling}

The degree of IPO underpricing is explained with the help of signaling theory. This theory perceives that issuer would like to "leave good taste" in investors' mouth to ensure the success of future equity offerings by inducing the degree of IPO underpricing. Welch [9] modeled the argument of signaling theory explaining that firms' underprice the issue deliberately to guarantee the favorable response to raise the funds through seasoned equity offerings in the future. In the model he argues that the high quality firms induce the degree of underpricing to signal their firm quality. The cost of signaling for high quality firm is lower as compared to low quality firm. If low quality firm tries to adopt the similar strategy, then they have to incur high imitation cost in the process of imitating the high quality firm. This is risky because market will be able to assess the true quality of a firm over a period of time. As a result, marginal cost of degree of underpricing is higher for low quality firms. Therefore, degree of underpricing is positively correlated with the firm quality. The model is supported empirically by considering the IPO dataset of 1028 firms between 1977 and 1982. It is observed that only 395 seasons equity offers were issued by 288 firms for the period of 1977 to 1987 however, the issue proceeds through seasoned equity offering was 3.4 times more than IPO proceeds.

Allen and Faulhaber [7] extended the signaling model during hot issue period. They build the model based on similar assumption of Ritter [47] that underpricing is observed at particular time and is industry specific. In such time period, the issuer gets benefited by signaling the firm quality through degree of underpricing due to superior information than the investors. The model is presented by categorizing firms into good and bad quality firms. The model supports that good firms underprice the IPO to signal the favorable dividend yield in future. Only good quality firms can follow this strategy because of their ability to compensate for the loss of proceeds incurred due to degree of underpricing. Therefore, degree of underpricing is positively linked with the firm quality that is defined in terms of expected dividend yield.

Grinblatt and Hwang [8] support signaling theory by developing a model based on the same assumption that issuer is risk averse and well informed about the future cash flows. To signal the true value of the firm the issuer retain fractional ownership stake and offer discount to mitigate the problem of information asymmetry existing between the issuer and investor about the true firm value. They add second dimension to explain the signaling theory by considering the variance of project cash flow (which are also unknown). The offer price is considered to signal the true value of the firm. They observed positive relationship between the degree of underpricing and intrinsic value of the firm.

All the above mentioned signaling models developed by Welch [9]; Allen and Faulhaber [7]; Grinblatt and Hwang [8] assume that the issuer is well informed about the firm's prospects than the investors. The issuer initially issues a partial offer through which information creation takes place. The good quality firms incur the initial cost of underpricing to communicate their quality to the investors. On the other hand bad quality firms will refrain from doing the same for two reasons. 1) For such firms, marginal cost of underpricing is quite high and 2) These firms are at risk of exposing their true quality to the investors over a period of time. The role of issuer and the underwriter is considered as a single entity. Information cascading theory or signaling theory assumes that the firm has fixed amount of authorized capital however the offers are made partially based on issuer's decision about the issued capital. Therefore, in such situation first partial issue of capital helps in information creation and dissemination. As a result, success of this issue is considered 
for the subsequent offer to signal the firm quality or to generate the information cascade where other investors get benefited through the information creation in the early phase. The models may have limitation if the firms try to raise the capital through other sources such as public debt after IPO than opting for seasoned equity offerings.

Slovin [48] empirically tested the relationship between the degree of IPO underpricing and the returns on seasoned equity offering (SEO). Underpricing has potential of mitigating negative reaction in response to the issuance of SEO. The event study results of 175 U.S. IPOs between 1971 and 1986 reveal that by inducing degree of IPO underpricing, firms will be able to reduce the shareholders loss by $22 \%$ in response to issuance of SEO. These results corroborate the findings of Welch [9] where degree of underpricing is induced to ensure the success of further equity offerings. On the contrary, the study by Michaely and Shaw [29] reject the signaling hypothesis. They studied IPO issued during the period of 1984 to 1988 with the total sample of 947 IPOs in U.S. market and tested the relationship between initial underpricing and reissuance of equity offering in future by formulating a simultaneous equation model. Empirically they found that the firms with greater degree of IPO underpricing visit capital market less frequently for seasoned equity offering with smaller issue size. Signaling theory is more suitable when the firm has a threshold of authorized capital and it issues the capital partially in sequence.

Based on these studies it is inferred that the issuance of IPO and associated degree of underpricing has dynamic effect of signaling to the investors. The signaling effect influences the performance of IPO, success of the issue (oversubscription or demand) and success of further equity offerings.

In sum, the theoretical construct of signaling theory supports that degree of underpricing and firm quality are positively related. The issuer is well informed about its growth prospects and voluntarily induces the degree of underpricing as a signaling strategy. However, in current scenario these studies have changed its context and relative significance due to change in the IPO process and regulatory environment. As a result, various assumptions of the theoretical model can be relaxed. The change in environment such as advancement in information technology helps in information dissemination much faster and inexpensive way. The book building process maintains the confidentiality of investors' identity. The role of underwriter is quite influential since the process is delegated for underwriting, pricing and distribution of the issue. The certification effect associated with the underwriter reputation is significant in determining the degree of IPO underpricing. The literature also presents various empirical studies testing the signaling theory.

In addition to the explanation of degree of IPO underpricing based on theoretical and empirical construct of information asymmetry and signaling, the review of literature is set out to identify the various factors that are considered as proxy for the quantification of degree of information asymmetry or signaling. These common factors have been broadly categorized as follows, a) Issue Specific factors, b) Firm Specific factors which are endogenous in nature, and c) Economy Specific factors influencing exogenously. These factors potentially mitigate or accentuate the degree of information asymmetry depending on its impact in the existing regulatory framework in a given economy.

Some of these factors also exhibit contradictory results when tested in different economies due to country specific idiosyncrasies. Many of these factors can be determined and addressed by the issuer. For example, issuer can decide on issue mechanism if the country specific regulator provides an option. If the regulator imposes a common issue mechanism either auction or book building then this will have differential impact on price discovery depending on other issue characteristics like size of the issue, premium etc.

In the following sections we further elaborate various factors within each category.. The discussion is focused on the potential of each factor in influencing the degree of information asymmetry leading to IPO underpricing as evidenced in the literature.

\section{Issue Specific Factors}

Information disclosed by the issuer about the issue and the firm through draft offer document is diligently evaluated by prospective investors. The investors' conduct their assessment of firm valuation and hence have a perception regarding its offer price. In addition to the disclosed information, various issue specific attributes are evaluated and thus the price perception of investor determines the success factor of IPO. At the outset, we briefly present the process of IPO. 


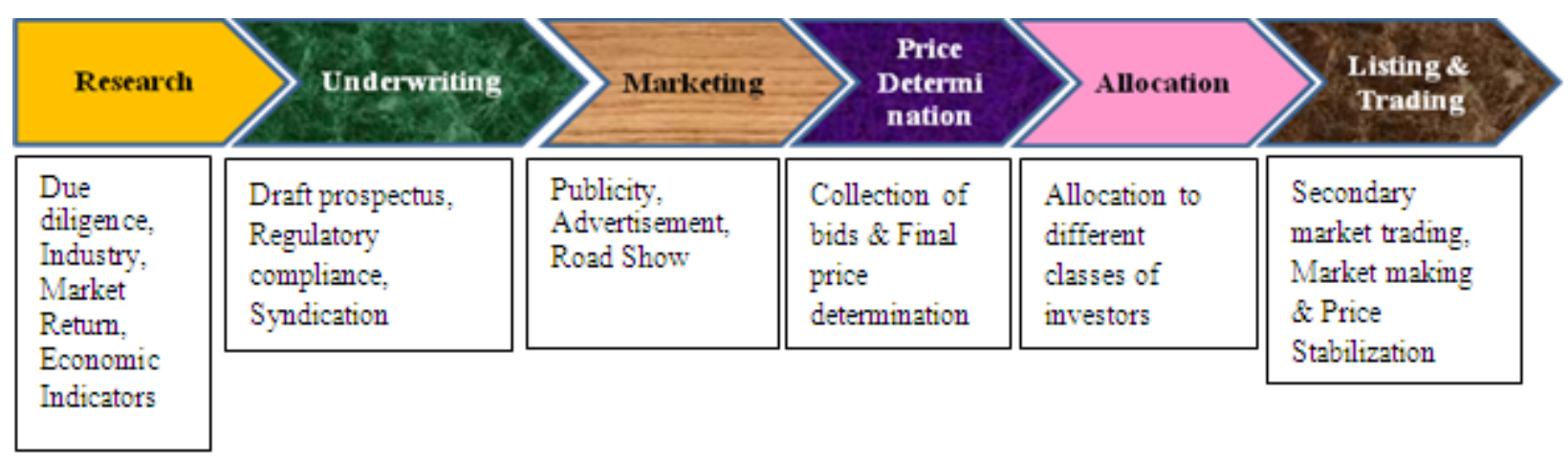

Figure 1. Steps involved in the process of IPO

The IPO process can be differentiated into various phases based on the activities involved in each phase as presented in figure 1. Each phase is described as follows:

- Research: This is the first step in the process after firm takes a decision of going public. A public going firm appoints an underwriter and normally underwriter carries out the process on behalf of the issuer. This step involves research related activities that are important to initiate the process of IPO. Once the firm decides to go public, normally they appoint underwriters to facilitate the IPO process. During this initial phase, the research division of an underwriting firm carries out a process of due diligence by evaluating macroeconomic indicators such as inflation, savings and investment, GDP growth, trends in the capital market, IPO cycles, market timing and impact of other IPO reaching market around the same time. In addition they also look for the industry specific information such as overall industry growth and its potential in the future, industry returns, capital structure of the industry and various financial ratios that are specific to the industry.

- Underwriting: Underwriting is the next step in IPO process after research. The role of lead manager is extremely important in this phase. It involves the preparation of draft prospectus that needs to be filed with regulatory authorities and registrar of the company. The data collected in the phase of research helps as an input to prepare the document. This stage also requires fulfillment of other requirement such as approval from the exchange through which the securities are listed and traded. This phase is also important in determining the syndicate structure of the investment banks that are involved in the issue. Lead manager in consultation with the issuer decides to select co-managers and other underwriters based on the geographical requirement and size of the issue.

- Marketing: The third phase in the IPO process involves marketing and publicity of an issue. Lead manager with the help of other syndicate members conducts the road show in various geographical locations to increase the awareness of the retail investors about the issue. The media coverage and advertising are targeted to attract the investors. The lead manager also publicizes the issue to various institutional investors through road shows.

- Price determination: The next phase is price determination that involves coordination between large numbers of activities once the issue opens. It includes receiving the bids from the investors belonging to various classes, recording the price and quantity demanded, tracking the payment and changes in case if the bids are revised. This process involves lot of data handling. To match the bids with price and quantity, electronic book is maintained and automated system displays the status of the book at the end of the day based on everyday demand till the issue is closed. Based on the demand underwriter in consultation with the issuer determines the final offer price. The process is more or less same in any country if it follows the book building mechanism. In case of auction or fixed price the process follows different method to finalize the offer process. These two processes show larger variation in terms of price determination in different economies. However, auction process is largely discontinued in most of the countries [49] and very few countries still opt fixed price method where the offer price is determined by the underwriter in consultation with issuer a priori to issue open date.

- Allocation: The next phase of the IPO process involves allocation of the shares to the prospective investors. The bids collected in the prior stage are processed to determine the price and this price is treated as a cut off price for the allocation purpose. In many countries underwriters have discretionary power of allocation. If underwriter does not have discretionary power, then the allocation of the shares takes place on pro rata basis where the ratio of oversubscription determines the number of shares allocated to each investors. This method is followed in India.

- Listing and trading: The final phase of the IPO is listing of securities on the exchange that normally takes place within a week after the allocation process is completed. 
Based on the IPO process as described above, different factors play important role at different stages of the IPO process. The critical issue specific factors having significant impact on the degree of underpricing are mainly issue size and issue mechanism.

Michaely and Shaw [29] observed that successful subscription of larger issues is highly dependent on attracting majority of the investor pool. This increases the variance of information asymmetry to be addressed by the issuers while pricing the issue. Everything remaining the same it is observed that this leads to the larger issues being underpriced significantly to increase their probability of success.

The second significant issue specific factor is issue mechanism adopted by the issuer if a choice exists. The issue mechanism is found to have significant influence in the price discovery process. The issue mechanisms available and prescribed by the regulators are aimed at mitigating the problem of information asymmetry and increase the efficiency of the price discovery process. These have been evolved over a period of time and converged into the following three models 1) auction, 2) fixed pricing and 3) book building and one or a couple of them are followed in almost all IPO markets.

\subsection{Auction and Fixed Pricing Mechanism}

There are mainly two types of auction mechanisms mentioned in the literature such as 1) Pay as bid auction or discriminatory auction and 2) Uniform price auction. These two categories are formed based on the price paid by the investors who participate in the IPO process through auction. Pay as bid offer differs from uniform price offer in terms of the differential price paid by the investors depending on their bids whereas in uniform price the auctioneer determines the market clearing price and winning bids above that price, pay the market clearing price. The uniform price auction became more popular as compared to pay as bid or discriminatory price auction. The mechanism of uniform price auction was closer to the book building process. Most of the studies in literature address uniform price auctions. Jagannathan and Sherman [49] found that auction method was quite successful in determining the price for fixed income security such as government bonds however, it was not appropriate for pricing the equity securities. Due to inefficient pricing, IPOs through auction method exhibited greater volatility in aftermarket return since the prices try to converge to fair price in the secondary market. Therefore, they find that investors of auction priced IPOs were better off in flipping the shares on the first day of trading where they get benefited through guaranteed positive return on their investment. This is one of the main reasons why many countries did not continue for longer time with auction process for IPO issuance (for example Singapore). Jagannathan and Sherman [49] also found that auction had greater degree of uncertainty over number of participants and number of bids received. Too many or very few entries in the auction created a problem to risk averse issuers and reduce the probability of success of the issue. Therefore, issuers were more concerned about the post listing liquidity and its impact on future equity offerings by following auction.

Studies reported in the literature based on auction pricing indicate that IPOs through this mechanism resulted in higher degree of underpricing, greater volatility, increased failure in attracting long term strategic investor and risk of over/under subscription of the issue due to inefficiency in the price determination process. Evidence from literature also indicates that IPOs through auction method have experienced greater degree of winner's curse/lemon problem, which hampered efficient price discovery and accentuated the problem of underpricing. This led to the abandonment of auction method by most IPO markets and substituted by fixed pricing mechanism and/or book building mechanism.

The fundamental difference between auction pricing and fixed price method was observed in case of participation of investor in determining the offer price. In fixed price offers, price discovery process is completely devoid of investors' participation and is finalized by the issuer. Therefore the accuracy of issue price depends upon the issuer's ability to ascertain the variance of information asymmetry between various classes of investors and also on the issuer's degree of risk averseness. Since it is very difficult to ascertain the variance of information asymmetry, ceteris paribus, a risk averse issuer would lower the price (inducing higher discount) to reduce the probability of under subscription. This method was found to be more suitable for small size IPOs due to the costs involved in book building and also in relatively less developed markets where investors are not capable to critically evaluate the available information. In all other cases, fixed price issues always led the trade-off between risk appetite of the issuer and degree of underpricing. However, in comparison with auction, it helped the investors to obtain positive return beyond first day of trading. Auction and fixed pricing mechanisms offered variation in the process of setting the offer price. Both these processes are found to have limitations in reducing and managing the impact of degree of information asymmetry in the price discovery process. This led to the introduction of book building mechanism in the early 90 's to encourage investors' participation in the price discovery process before the same can be frozen. The process of book building is designed in such a way that the investors do not compete among themselves for the successful bids based on available information. Following section elaborates on the efficacy of book building mechanism reviewed from the literature.

\subsection{Book Building Mechanism}

Book building method allows the issuer to reduce the variance in the magnitude of information asymmetry between various classes of investor by allowing flexible bids by prospective investors within a predetermined price range. This process enables the issuer to factor into the final price by considering collective information available with the market as a whole and arrive at a price closer to its intrinsic 
value as perceived by the investors. Biais and Faugeron-Crouzet [50] developed a model showing that the process of book building is successful in reducing the degree of underpricing due to its dynamic pricing mechanism.

Pre IPO marketing activities involved in the book building process gives indication of investors' interest and anticipated demand. The underwriters make use of this information in price setting. Information obtained prior to the bid opening date gets transformed to revise the price if required. The process of book building involves costs associated with marketing activities and underwriter fees. Therefore, the issuer has to consider cost benefit analysis in terms of issue cost and reduction in the degree of underpricing while opting for book building method. Ljungqvist [51] reported that the positive effect of lowering the degree of underpricing outweighs the cost in terms of fees paid to the underwriter and marketing efforts. However, the book building process has been criticized for inducing the allocation bias by the underwriter. Lee [52]; Cornelli and Goldreich [53]; Aggarwal [54]; Jenkinson and Jones [55] reported that discretionary power of allocation held by the underwriter in the process of book building creates inefficiencies in the price discovery process. Literature concludes that allocation process carried by the underwriters is biased towards institutional investors.

The success of book building process in reducing degree of underpricing depends upon country specific environmental factors. Kaneko and Pettway [56] studied 946 Japanese IPOs between 1993 and 2001 and compared the degree of underpricing of IPOs issued through book building and auction method. The results of this study have shown that IPOs issued through book-building resulted in higher degree of underpricing (48\%) than the ones through auction method (11.4\%). In Japan the process of book building was introduced in September, 1997. The study phase is initial time period since the introduction of book building, most of the book built IPOs set the offer price too low to ensure the success. Similarly, Derrien and Womack [57] study 264 French equity offerings between 1992 and 1998 and observed that auction method exhibits less underpricing as compared to book building method. The study supports that French IPOs through auction are less underpriced because auction method has ability to incorporate most recent market information in the final price than that of the book building. They arrive at this conclusion by observing the interaction effect of IPO issuance mechanism with market return and market volatility. Empirically it is observed that the variable market return and market volatility shows greater sensitivity towards the IPO underpricing that follow book building mechanism. The significance of interaction effect of market volatility and book building mechanism in determining the degree of underpricing has greater magnitude (with higher beta coefficient) than fixed price issues and book building issues. Therefore, this study infers that degree of underpricing of IPO issued through auction has greater ability to control the market reactions than the other methods in France.
In sum, it is evident from the literature that the issue mechanism adopted for IPO issuance plays important role in determining the degree of underpricing. The above mentioned studies show that though book building is successful in reducing the degree of underpricing in most of the countries, it does not completely eliminate the degree of underpricing. Also there are exceptions such as Japan and France where the process of book building is not successful in reducing the degree of underpricing as compared to other issue mechanisms. The reason that the degree of information asymmetry cannot be completely controllable though issue mechanism alone. The interaction of various firm specific characteristic and macroeconomic characteristics plays significant role.

\subsection{Role of Underwriter}

Involvement of underwriter in the process of IPO has significant impact on the pricing, after market liquidity and price stabilization process in the secondary market. Studies in the extant literature explored influence of underwriter reputation on IPO underpricing. It is found that well reputed underwriters are able to price the issue more accurately and attract long term investors. Carter and Manaster [15] found that offerings by well reputed underwriters are associated with less risk and result in lower degree of underpricing. Therefore, if the issue is associated with well reputed underwriters, the investors are confident about the investment in that issue. In addition, reputed underwriters use their clientele to make the issue successful (Carter [16]; Dunbar [58]; Beatty and Welch [59]; Carter and Dark [60]). Hence, well reputed underwriters are successful in reducing the degree of IPO underpricing. Therefore, selection of an underwriter is pivotal in the process of IPO issuance.

Dunbar [58] reported that fair pricing of IPO influences the market share of underwriter. Therefore, well reputed underwriters make serious attempt to price the issue more accurately. Hence, they are successful in reducing the degree of underpricing. Beatty and Welch [59] also support the certification hypothesis related to the underwriter reputation. Highly reputed underwriters are able to assess the firm value more accurately. Hence, degree of underpricing and reputation of underwriter are correlated. Underwriter's reputation provides information about the type of investors (clientele) they serve. If the underwriters' reputation is low, then the short term investors are attracted who participate in the flipping activities to obtain quick gains, hence the volatility of aftermarket returns increases. Highly reputed underwriters attract long term investors and help in improving the long term performance (Carter and Dark [60]).

In addition to the underwriter reputation, syndicate size and structure of underwriters involved in the issue also has critical role in influencing the price of IPO. Larger syndicates help in information production which is useful in price revision of IPO. Corwin and Schultz [61] do not find the significance of syndicate structure in determining the 
degree of underpricing. However, they support that larger syndicate structure is useful in information production and aftermarket activities. On the other hand, increase in the syndicate size will lead to increase in the issue expense. Underwriter reputation depends upon various factors such as number and size of IPO underwritten, industry, share in IPO market, percentage of successful IPOs, marketing network and geographical coverage of IPO market. Moreover, the experience in managing various activities involved in the process of IPO helps underwriter in complying with country specific regulatory norms. All these parameters influence the accuracy of valuation and success of IPO in the form of higher initial demand (higher oversubscription ratio). Higher demand indicates investors' interest to invest in a particular security. Therefore, reputation of underwriter and oversubscription ratio is highly correlated.

Public going firm would like to engage an underwriter in the process of IPO that guarantees maximum issue proceeds (Yeoman [62]). In addition to price determination, role of underwriter is also critical in aftermarket activities such as market maker for price stabilization once the secondary trading commences. Since underwriter acts as an intermediary between the firm and the investor, it controls the interaction between demand and supply of the issue (Ritter and Welch [26]). As underwriters are involved in the allocation process, they are well aware about the identity of the shareholders who are primary owners. Therefore, this information helps in circumventing any abnormalities in price stabilization due to mismatch between supply and demand (termed as market making) in the secondary market. Underwriters cover their short position by serving as a market maker (Ellis [35]). As a result it enables the underwriter to control the gap between demand and supply. The study by Krigman [34] shows that underwriters misprice the security intentionally because there is no direct penalty for mispricing the IPOs. Therefore, it justifies the act of money left on the table by underwriters as reported by Loughran and Ritter [63].

On one side reputation of the underwriter influence pricing of the issue and on the other side underwriters are critiqued for misusing their discretionary power of share allocation by favoring institutional investors. Loughran and Ritter [63] found that underwriters intentionally leave money on the table and induce bias to allocate the underpriced shares to buy-side investors. With the support of aforementioned studies, it can be summarized that the underwriter expertise to price the issue and discretionary power of allocation is important in influencing the price of IPO. However, the opportunistic behavior of the underwriter can be controlled by limiting their discretionary power through regulatory constraints.

\section{Firm Specific Factors}

Chemmanur and Paeglis [64]; Dewenter [65] pointed out that the firm specific characteristics are critical in determining the degree of IPO underpricing. The firm specific characteristics such as age, size, industry, ownership structure, brand loyalty, competitive advantage of a firm, evolution of firm, management quality and its reputation etc. are endogenous in nature. These attributes communicate certain implicit as well as explicit information regarding the firm and its prospects. Some industries are highly regulated and require greater amount of disclosure (for example financial services, aviation). Public going firms belonging to such industry are likely to have lower degree of information asymmetry due to the requirement of additional regulatory disclosures.

Similarly, ownership stake of insiders, managers and other stakeholders have an impact on the agency costs and have a bearing on the pricing. Such endogenous factors combined with their externalities affect the transparency or opaqueness of meaningful information useful for the purpose of valuation. Therefore, these firm specific factors have an impact on reducing or accentuating the degree of information asymmetry.

Issuance of any other securities and their performance prior to issuing an IPO helps the firm in reducing the degree of information asymmetry. The investors have access to evaluate these securities prior to making an investment decision into initial equity offering. An and Chan [66] report that IPOs preceded by credit rating prior to going public show lower degree of underpricing as compared to firms without credit rating.

These studies emphasize the role of firm specific factors on the degree of information asymmetry and eventually on degree of IPO underpricing. These firm specific factors are endogenous in nature and can be addressed by the firm once they are identified. Some of these important factors identified through literature are business group affiliation and ownership structure. The role of both these factors in determining the degree of underpricing is explained in the following section.

\subsection{Business Group Affiliation}

Business group affiliation is an important characteristic that influences the performance of member firms. Khanna and Rivkin [67] studied and compared the performance of business group affiliated firms in 14 emerging economies (Argentina, Brazil, Chile, India, Indonesia, Israel, Mexico, Peru, Philippines, South Africa, South Korea, Taiwan, Thailand, and Turkey). Their result supports that the influence of business group affiliation has positive influence on capital market efficiency measured in the form of capital market integration, turnover and availability of bank credit.

Another study by Khanna and Palepu [68] compared the performance of business group affiliated firms with stand-alone firms in Indian economy. They found the evidence that Indian business group affiliated firms' exhibit better performance as compared to stand alone firms. In emerging markets, the absence of intermediation results in higher transaction cost due to market imperfections. The 
reputation and network established by group affiliated firm helps in substituting the role of intermediaries. The advantage of incurring less transaction cost through economies of scale and scope is possible for group affiliated firms.

Gopalan [69] studied availability of internal capital market for business group member firms. They find greater evidence of intra-group loans that the member firm offers to weaker firm to avoid the bankruptcy of the weaker member firms. Internal capital market is used to finance the firm that is in financial distress at free of cost. This is done to avoid the negative spillover effect that will be created if the member firm goes bankrupt.

On the other hand Bertrand [70] studied 7521 Indian business groups consisting of 18600 firms and compared with 11079 standalone firms. In this study they found the evidence of expropriation of group resources supporting the tunneling hypothesis. They show that tunneling by Indian business houses is done through non-operating profits of a firm. They also find that the valuation done by market forces also consider the phenomenon of tunneling for the purpose of valuation. Therefore it may not be significant in determining the degree of IPO underpricing. Contrary to this argument, Friedman [71] supports the phenomenon of propping where entrepreneurs' use their personal money to support the firm when it is in trouble and benefit the minority shareholders. Therefore, tunneling and propping shows a reverse process and have distinct influence on the performance of firms that are affiliated to business group.

Kim and Sung [72] studied Chaebol, the business groups in Korea, have identified the reasons of Chaebol firms to go public. They observed that business group affiliated firms are more likely to go public a) if the ownership stake is concentrated with the family members that control the group; b) if there is low disparity between ownership and controlling stake by the group members; c) if the contribution by the firm to family's control is low; and d) if the firm is not benefited enough through its internal capital market. The study related to Korean-Chaebol exhibit greater degree of underpricing in the interest of maintaining the controlling stake for private benefit by the promoters (Chang [73]). On the other hand Cho and Lee [74] do not find significant difference between chaebol firms and standalone firms. The bias may be due to the time period of consideration for the empirical investigation.

The study of Japanese Keiretsu-affiliated firm shows that Keiretsu firms are less underpriced due to more stable earnings than other firms (Beckman [75]). The profit stabilization versus profit maximization principle adopted by a business group has significant impact on firm performance of group affiliated firm.

Another important aspect associated with the business group is degree of diversification of its operations. Khanna and Palepu [68] find that the degree of diversification has significant positive impact on firm performance up to a particular threshold of diversification. The degree of diversification brings in economies of scale and scope of operations which enables the firm to reduce the overall cost. It also helps the firm to explore new opportunity through synergy (Gomes and Livdan [76]). The linkage between the firm performance and degree of diversification is extrapolated to the shareholders' wealth and pricing of initial equity offerings. Boulton [77] identified that diversified firms are relatively less underpriced as compared to focused firms since degree of diversification helps in reducing information asymmetry.

These studies clearly indicate that business group affiliation and diversification has significant impact on the performance of member firms that influences the valuation of IPO. When business group affiliated firms decide to go public, the influence of business group is twofold. Firstly, business group helps in controlling the opaqueness of available information and secondly it provides certification effect due to its existing reputation. Fisman and Khanna [78] find that most often business group affiliated firms share the common pool of labor and its reputation. Therefore, IPO issuance by group affiliated firm gets advantage of its established network of other member firms and reduce degree of information asymmetry. Khanna and Rivkin [67] observed that the performances of member firms belonging to the same business group co-vary. Based on this established relationship, the investors can assess the performance of public going firm with the help of additional information associated with the business group and other firms associated with it. To support the argument of Gopalan [69] as mentioned above, the business group also helps in providing financial stability due to availability of internal credit.

Against this backdrop, firm characteristic of a group affiliation is linked with the degree of IPO underpricing. Ghosh [79]; Marisetty and Subrahmanyam [80] studied IPOs of Indian business group affiliated firms and empirically proved that IPOs belonging to business group affiliated firms show greater degree of underpricing than the stand alone firms. The study by Marisetty and Subrahmanyam [80] consider 2713 IPOs between 1991 and 2004. They attribute higher degree of underpricing due to tunneling effect that outweighs the certification effect associated with the business group affiliated firms. The study by Ghosh [79] analyzed 1842 Indian IPOs between 1993 and 2001 and finds that large equity issues of business group affiliated firms are more underpriced during hot market condition compared to stand alone firm. Further, they find the support for signaling theory where highly underpriced business group affiliated firms are likely to revisit the market to raise capital in future. Therefore, this study supports underpricing as a signaling strategy by group affiliated firms to leave good taste in investors' mouth to ensure the success of further equity offerings. On the contrary, Beckman [75] observed that business group affiliated firms of Japan (keiretsu) have shown lesser degree of underpricing than that of others since they are expected to produce stable earnings in the future. Lower degree of underpricing of keiretsu firms is also attributed to their relationship with the main bank. The close 
linkage with the financial institutions reduces the degree of information asymmetry where the earnings and other financial statements are disclosed. The choice of a firm between profit maximization and profit stabilization impacts the valuation of the firm. Therefore, the country specific environment in which business groups are operating is one of important determinants of its performance.

Based on the literature, it is concluded that performance of business group affiliated firms' significantly differs as that of standalone firms. Tunneling, propping and network effect influence the performance and valuation of the group affiliated firm. Similarly, degree of diversification of a business group and the firm has significant role in obtaining economies of scale and scope. The IPOs issued by group affiliated firms show mixed results in terms of its effect on the degree of IPO underpricing. The empirical results are based on country specific environment and specific features of a business group.

\subsection{Ownership Structure}

Ownership stake of promoters, managers and other institutional investors helps in signaling the agency related matters. Since, pre-IPO ownership is concentrated with few promoters/entrepreneurs there is less monitoring cost and low liquidity to promoters' wealth. Ownership structure of a public going firm is closely linked with liquidity and monitoring. Issuance of IPO brings liquidity to owners' fund and provides dispersed ownership that increases the monitoring cost. Pagano and Roell [81] find that ownership held by the promoters' act as a signal of firm quality to the investors. The owners have superior information. The process of liquidating the promoters' stake through IPO provides signals and investors get information about the companies' prospects. In case of IPO, the regulators enforce the lockup period where insiders cannot trade for fixed duration and insider information is secured and does not influence the price of the security.

The duration of lockup period is determined by the regulator and differs for each country. The restriction through lockup is required to control the participation of insiders who are at information advantage (including promoters, employees, and venture capital investors) in selling their stock holdings in the secondary market. Other investors can interpret the action of insider and it influences the trading volume and price in the secondary market. Brav and Gompers [91] propose three possible explanations for the existence of lockup period. The first possible explanation supports signaling hypothesis. The promoters of high quality firm would like to retain the larger ownership stake for longer time period. Hence it signals the firm quality. Second possible explanation is based on commitment hypothesis where lockup period serves as commitment device where the volume, volatility and price reaction is controlled during the initial trading period. The reputed underwriters are less likely to release the lockup provision early than the actual expiration period. This is possible if the country specific regulatory norms offer the discretionary power of early release of expiration period with the underwriter. And the third possible explanation is linked with the discretionary power of underwriter to release the early lockup. Underwriters are likely to demand additional compensation to execute the trade prior to lockup expiration. Brav and Gompers [91] empirically tested these three possible explanations. Out of these three, empirically they found support only for commitment hypothesis. Their empirical results support the price decline after lockup expiration period due to downward sloping demand curve supporting similar findings by Field and Hanka [98]. Therefore, lockup period is used to overcome information asymmetry. Their empirical findings support that the firms are likely to subject to greater information asymmetry have longer lockup period.

Based on the above explanation associated with lockup period, we interpret that the ownership structure and the proportion of ownership held by various stakeholders that are subject to the trading restriction under the lockup period are likely to influence the IPO returns.

Booth and Chua [36] developed a model and tested empirically that the degree of underpricing is necessary to obtain the initial dispersion of ownership through higher oversubscription because it has greater influence on the liquidity in the secondary market. Stoughton and Zechner [82] explain the degree of underpricing as one of the tool to attract block holders who actively take part in monitoring activities. Supporting the same with Rock's [1] argument, institutional investors participate only in the underpriced issues and underpricing is induced to attract the block holders.

The ownership stake of managers' is an important determinant of IPO underpricing. Aggarwal [54] developed a model, proves that managers induce degree of underpricing to maximize their wealth. Therefore, the degree of underpricing is positively influenced by percentage ownership held by the managers. The increased first day return shifts the demand curve upwards and the managers strategically diversify the fund invested after the lockup expiration period at higher price. As managers would like to maximize their wealth by underpricing the IPO, their motivation to bargain for higher offer price with underwriter is very low (Loughran and Ritter [63]) resulting in higher degree of underpricing.

Involvement of venture capital investors in pre-IPO ownership structure has influence on the pricing of IPO. The influence of venture capital (VC) investor is explained with the help of two phenomena such as certification effect associated with reputation of $\mathrm{VC}$ investors and grandstanding hypothesis. The empirical study by Megginson and Weiss [83] compared VC backed IPOs with non-VC backed IPO by considering 320 IPOs of each category between January 1983 and September 1987 issued in the United States. Their results support the certification effect associated with VC backed IPOs since VCs are able to assess the firm value accurately. Therefore, VC backed IPOs are less underpriced. On the contrary, Lee and Wahal [84] 
observe greater degree of underpricing associated with $\mathrm{VC}$ backed IPOs. They consider 6,413 U.S. IPOs between 1980 and 2000. This study support grandstanding hypothesis where obtaining liquidity to invested funds by VCs influence the reputation of $\mathrm{VC}$ and has positive influence on future fund raising. Therefore, underpricing is induced by venture capital investors for successful exit strategy for their investment.

Given the above it is inferred that pre-IPO ownership structure has greater influence on the degree of underpricing. Involvement of institutional investors provides active monitoring helps in reducing the degree of information asymmetry. The ownership stake of promoters, other institutional investors and managers influence the degree of IPO underpricing. Therefore, pre-IPO ownership structure of a firm plays pivotal role in determining degree of IPO underpricing.

\section{Economy Specific Factors}

In the previous section we described significance of issue specific and firm specific factors in determining the degree of IPO underpricing. Most of these factors are endogenous in nature. When the process of IPO issuance is carried out, the external environmental factors have significant impact on the information flow, price perception, probability of success of the issue, and its impact on the security prices. Such exogenous factors also influence the decision of going public. Therefore, macroeconomic environmental factors are critical in influencing the degree of information asymmetry and consequently degree of IPO underpricing. Some of these factors identified through literature are timing of IPO issuance, signaling by the firm and waves or IPO cycles. Following section elaborates on each one of these factors supported through literature.

\subsection{Theory of Market Timing}

The decision of "When to issue initial equity offering?" is quite critical for the issuer. Market timing theory justify the decision of issuer based on market timing by considering different market parameters such as volatility, number of IPOs belonging to the same industry and IPO volume in the market.

Market timing of IPO is differentiated into "Hot" and "Cold" market period. In hot market period large number of firms issue IPOs. Ritter [47] studied 1028 IPOs from 1977 to 1982 and observed that the period of January 1980 to March 1981 was hot market period (325 issues) with the mean underpricing of $48.4 \%$ as compared to $16.3 \%$ during other time period. Through time series analysis they analyzed two types of industries -1 ) industry heavily dependent on natural resources (oil and gas) and 2) industry that is referred as non-natural. Both types of industries showed positive correlation between risk and average degree of underpricing.
For the industry dependent on natural resource, the time series was found non-stationary.

Lucas and McDonald [85] give reasoning for the same and find that adverse macroeconomic or industry related conditions can lead to undervaluation of firm. In such cases, the issuer will hold the decision of going public because it will not fetch appropriate price in comparison with the market return and influence the probability of success of an IPO.

Beneveniste [86] empirically studied 6181 public issues between 1985 and 2000 from the U.S. and observed that public going firms get advantage of issues offered by their industry peers. The public going firms gets benefited through the information spillover enabling indirect learning for an issuing firm that is exhibited through price revision. As a result, this indirect learning helps the firm to take advantage and anticipate issue related uncertainties instead of relying through direct learning that takes place through the process of book building. This situation allows large underwriters to spread the cost of information that leads to degree of underpricing over multiple issues.

Colaco [87] empirically tested the theory of industry learning through peers by considering a sample of 3090 U.S. IPOs issued between 1993 and 2002. Their results showed that firms do not take advantage of learning through industry peers because of their need for capital and urge to diversify promoters' wealth. Bouis [88] studied 4524 IPOs between 1986 and 2007. The study examined the time period between filing of registration statement and the actual issuance date and found that the firms opt to go public when the market returns are higher and the volatility is relatively low. This way the issuer tries to formulate short term market timing strategy to fetch high price for the IPO.

Schultz [89] proposed the theory of pseudo market timing. According to this theory, the managers take a decision of going public when they anticipate maximum likelihood of obtaining higher price for the IPO so that it can maximize the issue proceeds. Based on their anticipation, IPOs are launched when their valuation normally reaches the peak. However, most often issuers (managers) do not come to know about this peak and therefore, the offer price of other IPO issues keep increasing till the market reaches its peak and starts shows decelerating trend.

Literature indicates that market timing of IPO has significant impact on valuation, information production and dissemination and success of IPO. Therefore, decision of when to issue new equity has significant impact on degree of IPO underpricing.

With the above given explanation associated with various factors influencing the degree of IPO underpricing, we can categorize them in the form of endogenous which are firm specific factors and exogenous factors which are economy specific. In addition to these endogenous and exogenous factors, issuers have discretionary decision making capacity associated with most of the issue specific factors. We summarize the review in table 1 . 
Table 1. Review of Literature Describing Various Reasons of Underpricing

\begin{tabular}{|c|c|c|c|c|}
\hline Reasons of Underpricing & Theory/ Category & Author & Year & $\begin{array}{c}\text { Theoretical (T)/ } \\
\text { Empirical (E) }\end{array}$ \\
\hline Discount offered to attract investors & Mystery & Ibbotson and Jaffe [92] & 1975 & $\mathrm{E}$ \\
\hline Information asymmetry & $\begin{array}{l}\text { Information } \\
\text { asymmetry }\end{array}$ & Kevin Rock [1] & 1986 & $\mathrm{~T}$ \\
\hline Insider holding and ability to convey intrinsic value & Signaling & Grinblatt and Hwang [93] & 1989 & $\mathrm{~T}$ \\
\hline Signaling for the success of future issues & Signaling & Ivo Welch [9] & 1989 & $\mathrm{~T}, \mathrm{E}$ \\
\hline Herd behavior by investors & Cascading & Ivo Welch [10] & 1992 & $\mathrm{~T}$ \\
\hline Information production and insider ownership & Agency & Thomas Chemmanur [27] & 1993 & $\mathrm{~T}$ \\
\hline Reputation of underwriter influence the price & $\begin{array}{l}\text { Certification } \\
\text { Hypothesis }\end{array}$ & $\begin{array}{l}\text { Chemmanur and Fulghieri } \\
{[95]}\end{array}$ & 1994 & $\mathrm{~T}$ \\
\hline Analyst coverage-investors optimism & After market activity & Rajan and Servaes [96] & 1997 & $\mathrm{E}$ \\
\hline VC backed IPOs outperform & $\begin{array}{l}\text { Certification } \\
\text { Hypothesis }\end{array}$ & Bravand Gompers [97] & 1997 & $\mathrm{E}$ \\
\hline Reputed underwriter less Underpricing & $\begin{array}{l}\text { Certification } \\
\text { Hypothesis }\end{array}$ & R.B. Carter et al., [16] & 1998 & $\mathrm{E}$ \\
\hline Underperformance after Lockup expiration & After market activity & Field and Hanka [98] & 2001 & $\mathrm{E}$ \\
\hline $\begin{array}{c}\text { Role of underwriter in price stabilization; executing } \\
\text { overallotment option }\end{array}$ & Role of Intermediary & ReenaAggarwal [99] & 2000 & $\mathrm{E}$ \\
\hline Money left on the table by underwriter & Role of Intermediary & Loughran and Ritter [63] & 2002 & $\mathrm{E}$ \\
\hline Allocation bias & Role of Intermediary & $\begin{array}{c}\text { Reena Aggarwal et al., } \\
{[100]}\end{array}$ & 2002 & $\mathrm{E}$ \\
\hline Book building less risky & Issue mechanism & Ann Sherman [101] & 2005 & $\mathrm{~T}$ \\
\hline Pseudo Market timing & Market timing & Paul Schultz [89] & 2003 & $\mathrm{E}$ \\
\hline Managerial ownership and lockup expiration period & Agency & $\begin{array}{l}\text { Rajesh Aggarwal et } \\
\text { al.[54] }\end{array}$ & 2002 & $\mathrm{~T}, \mathrm{E}$ \\
\hline Flipping activity by institutional investors & After market activity & ReenaAggarwal [102] & 2003 & $\mathrm{E}$ \\
\hline $\begin{array}{l}\text { Auction less underpriced as compared to book } \\
\text { building }\end{array}$ & Issue mechanism & Derrien and Womack [57] & 2003 & $\mathrm{E}$ \\
\hline Underwriter and publicly available information & Role of Intermediary & Lowry and Schwert [103] & 2004 & $\mathrm{E}$ \\
\hline IPO features and syndicate structure of underwriter & Role of Intermediary & Corwin and Schultz [61] & 2005 & $\mathrm{E}$ \\
\hline $\begin{array}{l}\text { Survey of CFOs for reasons to go public and reasons } \\
\text { for underpricing }\end{array}$ & Theory and practices & Brau and Fawcett [104] & 2006 & $\mathrm{E}$ \\
\hline $\begin{array}{c}\text { Linkage between past IPO returns, investors } \\
\text { sentiment and future oversubscription }\end{array}$ & Macroeconomic & Kaustia and Knupfer [105] & 2008 & $\mathrm{E}$ \\
\hline Influence of credit rating on IPO underpricing & Firm specific & An and Chan [66] & 2008 & $\mathrm{E}$ \\
\hline Learning from industry peers & Macroeconomic & Colaco et al.[87] & 2009 & E \\
\hline
\end{tabular}

The enormous amount of literature identified different factors resulting in degree of IPO underpricing. However, the literature still leaves with open ended questions which are considered as scope for further research.

\section{Scope}

Even though IPO underpricing has enormous amount of literature, it still leaves with few open ended questions which are summarized in this section. Market timing theory elaborates on various capital market related cycles. However, the answer is not yet clear to identify the optimal time of IPO issuance during the organizational life cycle of a firm. Based on the industry, requirement of capital for a firm during the initiation phase or growth phase or a saturation phase, will have its implications on the degree of information asymmetry, opportunity cost of capital and utilization of capital resources. The literature is silent in identifying any optimal point for a firm to issue an IPO based on its operational conditions that can maximize the issue proceeds by minimizing the degree of IPO underpricing.

Another important aspect in the process of IPO is country specific regulatory environment which has significant impact on various exogenous factors those play critical role in determining the degree of IPO underpricing. The effect of various endogenous variables is governed by exogenous factors that are specific to particular regulatory environment. The relationship between IPO underpricing and regulatory framework can be linked with the theoretical framework created by particular regulatory environment. The regulatory environment significantly differs in terms of finalizing the offer price, discretionary powers extended to the underwriter, market microstructure and listing norms of IPO on the first 
day of trading, disclosure norms related to the utilization of issue proceeds, tax structure on capital gains etc. will have significant impact on the price. However, the direct implications and relative significance of these parameters are not evaluated in the IPO literature. The future direction of research can focus on understanding the relative significance of various factors in influencing the degree of underpricing in a given regulatory framework. The theoretical construct based on different regulatory constraints those appear in emerging and developed countries will have different implications on the pricing decision of IPO. With the focus of dynamic regulatory environment in emerging and developed economy, the theoretical model can be proposed in minimizing the degree of IPO underpricing.

With this comprehensive review of IPO literature, we agree the view point of Ritter and Welch [26] that early explanation of IPO underpricing based on degree of information asymmetry is overemphasized in the academic literature. The phenomenon of underpricing is ubiquitously observed. There are number of firm specific, issue specific and economy specific factors interact with various other market forces and create complexities that influence the price of IPO. Therefore, it is very difficult to explain the degree of IPO underpricing with the help of single theory or a factor that determines the degree of IPO underpricing. Over the years, advancement in information technology has increased the speed and cost of information dissemination. Most of the phases in IPO process are electronic and automated. The regulatory environment of many countries is also focused toward making the process more transparent. Therefore, the future research work can be focused on understanding the relative importance of various factors within a particular institutional framework that encompasses the country specific or economy specific regulatory structure. Behavioral studies can still shed some light on variability of IPO underpricing based on investors' participation and purchasing intent.

In spite of enormous amount of literature, there is very little understanding of degree of underpricing based on contract theory where IPO underpricing can be explained based on various covenants of contract between the issuer and the underwriter. This can be linked with country specific regulatory environment and legal enforcement of laws which is different for each market.

\section{Conclusions}

The review of literature indicates that large number of exogenous as well as endogenous factors and their interaction influence the price discovery process of IPO resulting in IPO underpricing in most of the markets. The understanding of IPO underpricing is enhanced over a period of time by relaxing some of the assumptions of initial models such as homogenous expectation of investors', considering the role of issuer and underwriter as a single entity, uniform wealth and utility function of all the investors, and restriction on short selling securities (Rock [1]) from prior work. The explanation of degree of underpricing is initiated based on two basic theories such as information asymmetry and signaling. Given the theoretical construct of these two theories, IPO literature includes various studies that modeled the degree of underpricing by considering proxies supporting these theories. This review identified various endogenous and exogenous factors that are categorized into issue specific, firm specific and economy specific, having significant influence on the degree of IPO underpricing that is observed ubiquitously.

Various issue specific factors such as issue size, issue mechanism and role of underwriter play significant role in determining the degree of underpricing. The transformation of pricing mechanism from auction/fixed pricing to book building mechanism has created additional complexities due to involvement of underwriter and discretionary power associated with them in the process of IPO.

Large number of firm specific factors helps in communicating different information having its implications on the degree of information asymmetry related to the issue and the firm itself. These factors also tend to influence the overall firm performance in the capital market. As a result, pricing of initial public offering also gets influenced by these factors which are endogenous in nature. This paper summarized these factors as credit rating of debt securities, group affiliation, ownership structure etc. The review also identified economy specific factors such as IPO cycle, hot and cold market period, industry cycle, exercise of green shoe option by the underwriter in the secondary market, liquidity on the listing day and market microstructure etc. as various exogenous factors that influence the price discovery process and price of an IPO on the listing day. We conclude the review by identifying the scope of future research in explaining the degree of underpricing. The future research can be focused on modeling the regulatory environment within a given economy with various constraints and linking its relative impact on the degree of underpricing. In addition, the question still remain unaddressed in analyzing the optimal point of going public during different phases of organizational life cycle of a firm operating in a particular industry, contract between the issuer and the underwriter. We conclude this review by agreeing to the fact that IPO underpricing is a complex phenomenon to explain with the help of single generalized theory.

\section{Acknowledgements}

The authors gratefully acknowledge support from Syndicate Bank Entrepreneurship Research and Training Center- IIT Kanpur. 


\section{REFERENCES}

[1] Rock, K., Why new issues are underpriced, Journal of Financial Economics, Vol.15, 187-212, 1986.

[2] Reilly, Frank K., and Hatfield, K., Investor experience with new stock, Financial Analysts Journal, Vol.25, 73-80, 1969.

[3] Rhee, G., A review of the new issue puzzles, Fourth OECD Round Table on Capital Market Reform in Asia to be held in Tokyo, Japan on April 9-10, 2002.

[4] Purnanandam, Amiyatosh K., and Swaminathan, B., Are IPOs underpriced? The Review of Financial Studies, Vol.17, 811-848, 2001.

[5] Baron, David P., A model of the demand for investment banking advising and distribution services for new issues, Journal of Finance, Vol.37, 955-976, 1982.

[6] Muscarella, Chris J., and Vetsuypens, Michael R., A simple test of Baron's model of IPO underpricing, Journal of Financial Economics, Vol.24, 125-136, 1989.

[7] Allen, F., and Faulhaber, Gerald R., Signaling by underpricing in the IPO market, Journal of Financial Economics, Vol.23, 303-324, 1989.

[8] Grinblatt, M., and Hwang, C. Y., Signaling and the pricing of unseasoned new issues, Journal of Finance, Vol.44, 393-420, 1989.

[9] Welch, I., Seasoned offerings, imitation costs and the underpricing of initial public offerings, Journal of Finance, Vol.44, 421-450, 1989.

[10] Welch, I., Sequential sales, learning and cascades, Journal of Finance, Vol.47, 695-732, 1992.

[11] Beatty, Randolph P., and Ritter, J., Investment banking, reputation, and the underpricing of initial public offerings, Journal of Financial Economics, Vol.15, 213-232, 1986.

[12] Booth, J., and Smith, R., Capital raising, underwriting and the certification hypothesis, Journal of Financial Economics, Vol.15, 261-281, 1986.

[13] Titman, S., and Trueman, B., Information quality and the valuation of new issues, Journal of Accounting \& Economics, Vol.8, 159-172.

[14] Balvers, R. J., McDonald, W., and Miller, R. E., Underpricing of new issues and the choice of auditors as a signal of investment banker reputation, Accounting Review, Vol.63, 605-622, 1988.

[15] Carter, Richard B., and Manaster, S., Initial public offerings and underwriter reputation, Journal of Finance, Vol.45, 1045-1067, 1990

[16] Carter, Richard B., Dark, Frederick H., and Singh, Ajai K., Underwriter reputation, initial returns, and the long run performance of IPO stocks, Journal of Finance, Vol.53, 285-311, 1998

[17] Tinic, Seha M., Anatomy of initial public offerings of common stock, Journal of Finance, Vol.43, 789-822, 1988.

[18] Hughes, Patricia J., and Thakor, Anjan V., Litigation risk, intermediation and the underpricing of initial public offerings, Review of Financial Studies, Vol.5, 709-742, 1992.
[19] Ritter, Jay R., The long run performance of initial public offerings, Journal of Finance, Vol.46, 3-27, 1991.

[20] Loughran, T., and Ritter, J. R., The new issues puzzle, Journal of Finance, Vol.50, 23-51, 1995.

[21] Shiller, R. J., Speculative prices and popular models, Journal of Economic Perspectives, Vol.4, 55-65, 1990.

[22] Camerer, C., Bubbles and fads in asset prices: A review of theory and evidence, Journal of Economic Surveys, Vol.3, $3-41,1989$.

[23] Jensen, Michael C., Agency costs of free cash flow, corporate finance and takeovers, American Economic Review, Vol.76, 323-339, 1986.

[24] Jain, Bharat A., and Kini, O., The post issue operating performance of IPO firms, Journal of Finance, Vol.49, 1699-1726, 1994.

[25] Cai, J., and Loughran, T., The performance of Japanese seasoned equity offerings, 1971-1992, Pacific-Basin Finance Journal, Vol.6, 395-426.

[26] Ritter, Jay R., and Welch, I., A review of IPO activity, pricing, and allocations, Journal of Finance, Vol.57, 1795-1828, 2002.

[27] Chemmanur, Thomas J., The pricing of initial public offers: A dynamic model with information production, Journal of Finance, Vol.48, 285-304, 1993.

[28] Jegadeesh, N., Weinstein, M., and Welch, I., An empirical investigation of IPO returns and subsequent equity offerings, Journal of Financial Economics, Vol.34, 153-175, 1993.

[29] Michaely, R., and Shaw, Wayne H., The pricing of initial public offerings: Tests of adverse selection and signaling theories, Review of Financial Studies, Vol.7, 279-319, 1994.

[30] Koh, F., and Walter, T., A direct test of Rock's model of the pricing of unseasoned issues, Journal of Financial Economics, Vol.23, 251-272, 1989.

[31] Drake, Philip D., and Vetsuypens, Michael R., IPO underpricing and insurance against legal liability, Financial Management, Vol.22, 64-73, 1993.

[32] Lowry, M., and Shu, S., Litigation risk and IPO underpricing, Journal of Financial Economics, Vol.65, 309-335, 2002.

[33] Boehmer, E., and Raymond Fishe, P., Equilibrium rationing in initial public offerings of equity, Working paper, University of Miami, 2001.

[34] Krigman, L., Shaw, Wayne H., and Womack, Kent L., The persistence of IPO mispricing and the predictive power of flipping, Journal of Finance, Vol.54, 1015-1044, 1999.

[35] Ellis, K., Michaely, R., and O'Hara, M., When the underwriter is the market maker: an examination of trading in the IPO aftermarket, Journal of Finance, Vol.55, 10391074, 2000.

[36] Booth, James R., and Chua, L., Ownership dispersion, costly information, and IPO underpricing, Journal of Financial Economics, Vol.41, 291-310, 1996.

[37] Baron, David P., and Holmstrom, B., The investment banking contract for new issues under asymmetric information: Delegation and the incentive problem, Journal of Finance, Vol.35, $1115-1138,1980$. 
[38] Benveniste, Lawrence M., and Spindt, Paul A., How investment bankers determine the offer price and allocation of new issues, Journal of Financial Economics, Vol.24, 343-362, 1989.

[39] Miller, Edward M., Risk, uncertainty, and divergence of opinion, Journal of Finance, Vol.32, 1151-1168, 1977.

[40] Khurshed, A., Paleari, S., Pande, A., and Vismara, S., Transparent book building, certification and initial public offerings, Journal of Financial Markets, Vol.19, 154-69, 2014.

[41] Neupane, S., and Poshakwale, S. S., Transparency in IPO mechanism: Retail investors' participation, IPO pricing and returns, Journal of Banking and Finance, Vol.36, 2064-76, 2012.

[42] Brooks, R. M., Mathew, P. G., and Yang, J. J., When-issued trading in the Indian IPO market, Journal of Financial Markets, Vol.19, 170-96, 2014.

[43] Neupane, S., Paudyal, K., and Thapa, C., Firm quality or market sentiment: What matters more for IPO investors? Journal of Banking and Finance, 44, 207-18, 2014.

[44] Deb, S. S., and Marisetty, V. B., Information content of IPO grading, Journal of Banking and Finance, Vol.34, 2294-305, 2014.

[45] Bubna, A., and Prabhala, N. R., IPOs with and without allocation discretion: Empirical evidence, Journal of Financial Intermediation, Vol.20, 530-61, 2011.

[46] Aggarwal, R., Allocation of initial public offerings and flipping activity, Journal of Financial Economics, Vol.68, 111-35, 2003.

[47] Ritter, Jay R., The "Hot Issue" market of 1980, Journal of Business, Vol.57, 215-240, 1984.

[48] Slovin, M. B., Sushka, M. E., and Bendeck, Y. M., Seasoned common stock issuance following an IPO, Journal of Banking and Finance, Vol.18, 207-226, 1994.

[49] Jagannathan, R., and Sherman, Ann E., Why do IPO auctions fail? NBER Working Paper Series, 12151, 2006.

[50] Biais, B., and Faugeron, Anne M., IPO auctions: English, Dutch, French and Internet, Journal of Financial Intermediation, Vol.11, 9-36, 2002.

[51] Ljungqvist, A., T. Jenkinson, P., and Wilhelm, Jr., W. J., Global integration in primary equity markets: The role of U.S. banks and U.S. investors, Review of Financial Studies, Vol.16, 63-99, 2003.

[52] Lee, Philip J., Taylor, Stephen L., and Walter, Terry S., IPO underpricing explanations: Implications from investor application and allocation schedules, Journal of Financial and Quantitative Analysis, Vol.34, 425-444, 1999.

[53] Cornelli, F., and Goldreich, D., Book building and strategic allocation, Journal of Finance, Vol.56, 2337-2369, 2001.

[54] Aggarwal, R., Krigman, L., and Womack. K., Strategic IPO underpricing, information momentum, and lockup expiration selling, Journal of Financial Economics, Vol.66, 105-137, 2002.

[55] Jenkinson, T., and Jones, H., IPO pricing and allocation: a survey of the views of institutional investors, Review of
Financial Studies, Vol.22, 1477-1504, 2009.

[56] Kaneko, T., and Pettway, R. H., Auctions versus book building of Japanese IPOs, Pacific-Basin Finance Journal, Vol.11, 439-462, 2003.

[57] Derrien, F., and Womack, Kent L., Auctions vs. book building and the control of underpricing in hot IPO markets, The Review of Financial Studies, Vol.16, 31-61, 2003.

[58] Dunbar, Craig G., Factors affecting investment bank initial public offering market share, Journal of Financial Economics, Vol.55, 3-41, 2000.

[59] Beatty, Randolph P., and Welch, I., Issuer expenses and legal liability in initial public offerings, Journal of Law and Economics, Vol.39, 545-602, 1996.

[60] Carter, Richard B., Dark, Frederick H., Underwriter reputation and initial public offers: the detrimental effects of flippers, The Financial Review, Vol.28, 279-301, 1993.

[61] Corwin, S. A., and Schultz, P., The role of IPO underwriting syndicates: Pricing, information production and underwriter competition, The Journal of Finance, Vol.60, 443-486, 2005.

[62] Yeoman, J.C., The optimal spread and offering price for underwritten securities, Journal of Financial Economics, Vol.62, 169-198, 2001.

[63] Loughran, T., and Ritter, Jay R., Why don't issuers get upset about leaving money on the table in IPOs?, Review of Financial Studies, Vol.15, 413-443, 2002.

[64] Chemmanur, T. J., and Paeglis, I., Management quality, certification, and initial public offerings, Journal of Financial Economics, Vol.76, 331-368, 2005.

[65] Dewenter, K., Novaes, W., and Pettway, R.H., Visibility versus complexity in business groups: Evidence from Japanese Keiretsu, Journal of Business, Vol.74, 79-100, 2001.

[66] An, H., and Chan, K., Credit ratings and IPO pricing, Journal of Corporate Finance, Vol.14, 584-595, 2008.

[67] Khanna, T., and Rivkin, J. W., Ties that bind business groups: Evidence from an emerging market, HBS Strategy Unit Working Paper No. 00-068, 2000.

[68] Khanna, T., and Palepu, K., Is group affiliation profitable in emerging markets? An analysis of diversified Indian business groups, Journal of Finance, Vol.55, 867-891, 2000.

[69] Gopalan R., Nanda, V., and Seru, A., Affiliated firms and financial support: Evidence from Indian business groups, Journal of Financial Economics, Vol.86, 759-795, 2007.

[70] Bertrand, M., Mehta, P., and Mullainathan, S., Ferreting out tunneling: An application to Indian business groups, Quarterly Journal of Economics, Vol.117, 121-147, 2002.

[71] Friedman, E. S., and Mitton, Johnson T., Propping and tunneling, Journal of Comparative Economics, Vol.31, 732-750, 2003.

[72] Kim, W., and Sung, T., What makes group-affiliated firms go public?, Working paper, KDI School of Public Policy \& Management Paper No. 05-10, 2005.

[73] Chang, S. J., Ownership structure, expropriation, and performance of group affiliated companies in Korea, Academy of Management Journal, Vol.46, 238-253, 2003. 
[74] Cho, S. H., and Lee, J., Group affiliation's effect on valuation and performance of IPO firms: Evidence on Korean Chaebols, Actual Problems of Economics, Vol.140, 445-459, 2013.

[75] Beckman, J., Garner, J., Marshall, B., and Okamura, H., The influence of underwriter reputation, keiretsu affiliation, and financial health on the underpricing of Japanese IPOs, Pacific-Basin Finance Journal, Vol.9, 513-534, 2001.

[76] Gomes, J., and Livdan, D., Optimal diversification, reconciling theory and evidence, Journal of Finance, Vol.59, 507-535, 2004.

[77] Boulton, Thomas J., Smart, Scott B., and Zutter, Chad J., Industrial diversification and underpricing of initial public offerings, Financial Management, Vol.42, 679-704, 2013.

[78] Fisman, Raymond J., and Khanna, T., Facilitating development: The role of business groups, World Development, Vol.32, 609-628, 2004.

[79] Ghosh, S., Underpricing of initial public offerings, Emerging Markets Finance and Trade, Vol.41, 45-57, 2005.

[80] Marisetty, V. B., and Subrahmanyam, M. G., Group affiliation and the performance of IPOs in the Indian stock market, Journal of Financial Markets, Vol.13, 196-223, 2010 .

[81] Pagano, M., and Roell, A., The choice of stock ownership structure: Agency costs, monitoring, and the decision to go public, Quarterly Journal of Economics, Vol.113, 187-225, 1998.

[82] Stoughton, Neal M., and Zechner, J., IPO - mechanisms, monitoring and ownership structure, Journal of Financial Economics, Vol.49, 45-77, 1998.

[83] Megginson, W., and Weiss, K., Venture capitalist certification in initial public offerings, Journal of Finance, Vol.46, 879-903, 1991.

[84] Lee, P. M., and Wahal, S., Grandstanding, certification and the underpricing of venture capital backed IPOs, Journal of Financial Economics, Vol.73, 375-407, 2004.

[85] Lucas, D., and McDonald, R., Equity issues and stock price dynamics, Journal of Finance, Vol.45, 1019-1043, 1990.

[86] Benveniste, L. M., Ljungqvist, A., Wilhelm Jr, W. J., and Yu, $\mathrm{X}$., Evidence of information spillovers in the production of investment banking services, Journal of Finance, Vol. 58, 577-608, 2003

[87] Colaco, H. M. J., Ghosh, C., Knopf, J. D., and Teall, J. L., IPOs, clustering, indirect learning and filing independently, Journal of Banking \& Finance, Vol.33, 2070-2079, 2009.

[88] Bouis, R., The short term timing of initial public offerings, Journal of Corporate Finance, Vol.15, 587-601, 2009

[89] Schultz, P., Pseudo market timing and the long-run underperformance of IPOs, Journal of Finance, Vol.68, 483-517, 2003
[90] Yong, Othman, A review of IPO research in Asia: What's next? Pacific-Basin Finance Journal, Vol. 15, 253-275, 2007.

[91] Brav, Alon, and Gompers, P., A., The role of lockups in initial public offerings, The Review of Financial Studies, Vol. 16, 1-29, 2003.

[92] Ibbotson, R.G., and J. Jaffe, Hot issue' markets, Journal of Finance, Vol.30, 1027-1042, 1975.

[93] Grinblatt, M., and C. Hwang, Signaling and the pricing of new issues, Journal of Finance, Vol. 44, 393-420, 1989.

[94] Chemmanur, Thomas J., The pricing of initial public offers: A dynamic model with information production, Journal of Finance, Vol. 48, 285-304, 1993.

[95] Chemmanur, Thomas J., and P. Fulghieri, Investment bank reputation, information production and financial intermediation, Journal of Finance, Vol. 49, 57-79, 1994.

[96] Rajan, Raghuram, and Henri Servaes, Analyst following of initial public offerings, Journal of Finance, Vol. 52, 507-529, 1997.

[97] Brav, A., and P. A. Gompers, Myth or reality? The long-run underperformance of initial public offerings: Evidence from venture and non-venture capital-backed companies, Journal of Finance 52, 1791- 1821, 1997.

[98] Field, Laura C., and Gordon Hanka, The expiration of IPO share lockups, Journal of Finance, Vol. 56, 471-500, 2001.

[99] Aggarwal, Reena, Stabilization activities by underwriters after initial public offerings, Journal of Finance, Vol. 55, 1075-1103, 2000.

[100] Aggarwal, Reena, Nagpurnanand R. Prabhala, and Manju Puri, Institutional allocation in initial public offerings: Empirical evidence, Journal of Finance, Vol. 57, 1421-1442, 2002.

[101] Sherman, Ann E. Global trends in IPO methods: Book building versus auctions with endogenous entry, Journal of Financial Economics, Vol. 78, 615-649, 2005.

[102] Aggarwal, Reena, Allocation of initial public offerings and flipping activity, Journal of Financial Economics, Vol. 68, $111-135,2003$.

[103] Lowry, M., and G. William Schwert, Is the IPO pricing process efficient? Journal of Financial Economics, 71, 3-26, 2004.

[104] Brau, James C., and Stanley Fawcett, Initial Public Offerings: An Analysis of Theory and Practice, Journal of Finance, Vol. 61, 399-436, 2006.

[105] Kaustia, Markku, and SamuliKnupfer, Do Investors Overweight Personal Experience? Evidence from IPO Subscriptions, Journal of Finance, Vol. 63, 2679-2702, 2008. 